\title{
Management of false passages in patients practising clean intermittent self catheterisation
}

\author{
DP Michielsen ${ }^{1}$ and JJ Wyndaele*,1 \\ ${ }^{1}$ Department of Urology, University of Antwerp, Wilrijkstraat, Edegem, Belgium
}

\begin{abstract}
Aim of study: Clean intermittent self catheterisation (CISC) is commonly used by patients with impaired bladder emptying. But how to manage acute false passages in patients on CISC? Methods: Six patients experienced difficulty when performing intermittent catheterisation. Urethrocystoscopy demonstrated a new false passage in all of them. Treatment consisted of urethral stenting with an $14-16 \mathrm{~F}$ indwelling catheter during $3-6$ weeks and antibiotic therapy for 5 days.

Results: The false passage disappeared on cystoscopy. During a mean follow up of 10 months (1-28 months), none of these patients developed another false passage. All are practising CISC without any further difficulty.

Conclusions: Analysis of our data suggests that temporary urethral stenting and antibiotic therapy are an excellent management in patients on CISC who develop an acute false passage.
\end{abstract}

Keywords: spinal cord injury; urinary catheterisation; urethral trauma

\section{Introduction}

Clean intermittent self-catheterisation (CISC) is now accepted as a method of choice for bladder emptying in spinal cord injury patients. Several studies have reported good preventive or therapeutic effects in hydronephrosis, vesicoureteral reflux, urinary tract infection and incontinence. ${ }^{1,2,3,4}$ Nevertheless, CISC may cause complications which are influenced by the length of follow-up. Most of the severe urethral complications are found in patients on CISC for more than 5 years.

Apart from urethral sphincter spasticity, urethral strictures and false passages cause obstruction to catheterisation. $^{4,5,6}$ If a patient on CISC develops urethral trauma with false passage, this can cause great difficulties for the following catheterisations and induce gradual worsening of the situation. We report our experience with the diagnosis and conservative treatment of acute false passage in patients on CISC.

\section{Methods}

During a 3 year prospective study of 69 male patients under our care practising clean intermittent selfcatheterisation (CISC) for neurovesical dysfunction, acute false passage was diagnosed in six patients $(9 \%)$ following the patient's acute inability to pass a catheter and confirmed by urethrocystoscopy. The clinical profile of the six patients is given in Table 1; all paraplegics were Frankel A. Patients consult our

*Correspondence: Professor JJ Wyndaele, Department of Urology, University of Antwerp, Wilrijstraat 10, 2650 Edegem, Belgium department twice a year for urological check-up with cystoscopy.

All spinal cord injuries had experienced some catheterisation difficulties due to sphincter spasm, which could not be adequately controlled with drugs. The patient with spina bifida was unable to pass the catheter 3 days before consulting. An indwelling catheter $(14-16 \mathrm{~F})$ stented the urethra in all our patients for 3 weeks. Thereafter an urethrocystoscopy was performed to control the healing of the urethra.

\section{Results}

The therapeutic details of the six patients are given in Table 1. The false passages were not deep: less than $5 \mathrm{~mm}$ in $4,1 \mathrm{~cm}$ in 1 and $1.5 \mathrm{~cm}$ in the patient with lumbosacral spina bifida. The urethrocystoscopy after cure revealed no clear scar tissue in four patients and catheterisation was restarted without any difficulty. In two patients a white scar tissue surrounded the remains of the false passages after 3 weeks. They were re-stented for another 3 weeks. After cure, the place of trauma could hardly be demonstrated. CISC was restarted. For 3 months the patients were seen at regular intervals to control recurrence of false passage. During a mean follow-up of 10 months (1-28 months), no patient developed another false passage.

Early after restarting CISC sphincter spasticity was described as less than at the time of trauma. A further evaluation in those with longer follow-up showed that they experienced an undulating pattern of sphincter spasticity. 
Table 1 Clinical profile of the 6 patients practising CISC

\begin{tabular}{|c|c|c|c|c|c|c|c|}
\hline Patient & $\begin{array}{c}\text { Age } \\
\text { (year) }\end{array}$ & Diagnosis & Catheter & $\begin{array}{c}\text { Duration } \\
\text { of } \\
\text { CISC (months) }\end{array}$ & $\begin{array}{c}\text { Frequency } \\
\text { of CISC } \\
(x / \text { day })\end{array}$ & $\begin{array}{l}\text { Localisation } \\
\text { of false } \\
\text { passage }\end{array}$ & $\begin{array}{l}\text { Indwelling } \\
\text { catheter }\end{array}$ \\
\hline 1 & 22 & $\begin{array}{l}\text { Traumatic } \\
\text { paraplegia } \\
\text { C5-C6 }\end{array}$ & Lofric & 61 & $5-6$ & $\begin{array}{l}\text { Urethral } \\
\text { sphincter } \\
12 \text { o'clock }\end{array}$ & 3 weeks \\
\hline 2 & 52 & $\begin{array}{l}\text { Lumbosacral } \\
\text { spina bifida }\end{array}$ & $\begin{array}{l}\text { Nelaton } \\
12\end{array}$ & 5 & 4 & $\begin{array}{l}\text { Urethral } \\
\text { sphincter } \\
5 \text { o'clock }\end{array}$ & 6 weeks \\
\hline 3 & 62 & $\begin{array}{l}\text { Traumatic } \\
\text { paraplegia } \\
\text { D12-L1 }\end{array}$ & $\begin{array}{l}\text { Nelaton } \\
12\end{array}$ & 119 & 4 & $\begin{array}{l}\text { Bulbar } \\
\text { urethra } \\
9 \text { o'clock }\end{array}$ & 3 weeks \\
\hline 4 & 32 & $\begin{array}{l}\text { Traumatic } \\
\text { paraplegia } \\
\text { D3-D4 }\end{array}$ & Lofric & 47 & $5-6$ & $\begin{array}{l}\text { Urethral } \\
\text { sphincter } \\
5 \text { and } 7 \text { o'clock }\end{array}$ & 3 weeks \\
\hline 5 & 26 & $\begin{array}{l}\text { Traumatic } \\
\text { paraplegia } \\
\text { D6-D7 }\end{array}$ & $\begin{array}{l}\text { Nelaton } \\
12\end{array}$ & 75 & $5-6$ & $\begin{array}{l}\text { Urethra } \\
\text { sphincter } \\
5 \text { and } 9 \text { o'clock }\end{array}$ & 3 weeks \\
\hline 6 & 30 & $\begin{array}{l}\text { Traumatic } \\
\text { paraplegia } \\
\text { D7-D8 }\end{array}$ & $\begin{array}{l}\text { Nelaton } \\
14\end{array}$ & 14 & $5-6$ & $\begin{array}{l}\text { Urethral } \\
\text { sphincter } \\
4 \text { o'clock }\end{array}$ & 6 weeks \\
\hline
\end{tabular}

\section{Discussion}

The introduction of intermittent catheterisation caused a revolution in the management of bladder dysfunction. In 1966 Guttmann and Frankel reported the successful use of sterile intermittent catheterisation in the management of neurogenic bladder in adults who had suffered a spinal cord injury. ${ }^{7}$ In 1972 Lapides and associates reported on clean intermittent catheterisation and stressed the importance of regular emptying rather than the sterility of the technique. ${ }^{5}$ Many others have reported the safety and efficiency of intermittent catheterisation in the management of bladder dysfunction in patients of all ages..$^{2,6,8,9,10}$ It is now one of the most important tools in the urologist's armament for these patients.

Several early reports presented reassuring results as for potential complications, especially urinary sepsis and renal deterioration. ${ }^{1}$ The long term clinical experience confirms the overall good results. ${ }^{2,3,4}$ Local trauma of the urethral wall, induced by repeated introduction of the catheter have been reported. Labat et $a l^{11}$ found modifications of the urethral wall, especially in male patients on CISC, who performed catheterisation for more than 1 year.

Urethral bleeding is not uncommon in new patients and occurs regularly in one third in the long term. ${ }^{12}$ Strictures and false passages seem to appear after several years. ${ }^{4}$ The incidence of urethral strictures was reported as $1 \%$ to $19 \%$ and seems to increase with follow-up. Bakke et $a l^{13}$ found a $1 \%$ incidence after a short follow-up of 1 year. Perrouin-Verbe et al ${ }^{14}$ reported $19 \%$ after 9.5 years of follow up. False passage was noted in $3 \%$ to $4 \%$ of the patients. ${ }^{4,15}$

Almost all reports in the literature describe the use of small catheters $(14-16 \mathrm{~F})$ and the liberal use of lubricants by male patients. ${ }^{4}$ This measure alone does not seem to prevent urethral irritation and trauma in the long term. Recently a hydrophylic low friction catheter has been introduced for CISC. When compared with ordinary plastic catheters used with lubrication, the friction of these catheters is $90 \%$ to $95 \%$ lower. The reason is that the surface of the low friction catheter consists of polyvinyl pyrrolidine, which absorbs water by binding the water molecules to the catheter surface. This provides a stable lubricating layer. The importance of the osmolality was shown by Waller et al. ${ }^{16}$ Hellström and associates $^{17}$ carried out a prospective study on the efficacy and safety in 15 females and 26 males over 40 months. There were no urethral complications, suggesting that the self-lubricating hydrophylic catheters may be less traumatic than those used previously. It is not yet known if patients on hydrophylic catheters will have less urethral complications during the longterm follow-up. A study by Waller et al indicates, in a 7 year follow-up, that patients who use hydrophylic low friction catheters do as well as patients using conventional catheters. ${ }^{18}$ However, we need controlled studies comparing the use of hydrophylic catheters and good quality non-lubricated catheters with intraurethrally injected lubrication.

In all but one of our patients, false passages occurred by traumatising the urethra at the site of the external sphincter, suggesting an influence of sphincter spasticity. Urethral false passage may complicate CISC in both sexes. Nevertheless the risk of trauma is higher in male patients and in those lacking urethral sensation. ${ }^{15}$ In female patients, it is unlikely to occur unless the patient has undergone a previous urethral or bladder neck suspension operation. 
The use of stiff plastic catheters, forceful manipulation while inserting the catheter, significant bleeding per urethram during catheterisation and urethral sphincter spasticity are important factors in the development of false passages. ${ }^{19,20}$ Thus, any patient on a CISC regimen with the above complaints needs careful follow-up. When difficulty with catheterisation occurs, urethrocystoscopy to diagnose the false passage should be performed. To permit bladder drainage and avoid further trauma, we stent the urethra with a $14-16 \mathrm{~F}$ silicon indwelling catheter for a first period of 3 weeks. We use a prophylactic antibiotic regimen (norfloxacin $400 \mathrm{mg}$ t.i.d or ciprofloxacin $250 \mathrm{mg}$ t.i.d) for the same period. Urethrography is not performed as it is not useful for the diagnosis of false passage: Koleilat et $a l^{19}$ examined nine patients with false passage diagnosed by urethrocystoscopy, but no false passage was detected by either antegrade or retrograde urethrography. Follow-up investigations consist of urethrocystoscopy after 3 weeks. If false passage is not healed, the urethra is stented for another 3 weeks.

A promising result has been obtained in our six patients. After 3-6 weeks, all patients could practise CISC without further difficulty. Our results confirm the data of Koleilat et al. ${ }^{19}$ They treated nine patients with false passage the same way. Seven patients were cured. Two patients had to abandon CISC. A boy who had undergone repair of bladder exstrophy and a woman who had undergone reconstruction of an epispadias deformity continued to have severe difficulty with catheterisation and they underwent continuous urinary diversion..

Mandal and Vaidyanathan ${ }^{20}$ had one patient with urethral stricture and false passage treated with an indwelling catheter. After removal of the stenting catheter, he was unable to catheterise himself. Therefore suprapubic cystostomy was done. After 24 months, he continued on suprapubic cystostomy drainage. We have no data to compare the treatment of acute false passage with transurethral versus suprapubic catheter.

We prefer the transurethral for the ease with which it can be used. The danger of inducing other complications is limited as the catheter has to remain in place only for a few weeks. Antibiotics were given to prevent the development of paraurethral abcess. It appears from our results that a false passage up to $1.5 \mathrm{~cm}$ can produce a complete cure if further traumatisation or infection can be prevented.

Temporary urethral stenting and antibiotic therapy seem a good therapeutic option to treat patients with acute false passage and has a great chance that further CISC will remain possible.

\section{References}

1 Lapides J, Diokno AC, Gould FR, Lowe BS. Further observation of self catheterisation. J Urol 1976; 116: 169-171.

2 Diokna AC, Sonda PL, Hollander JB, Lapides J. Fate of patients started on clean intermittent self-catheterization therapy 10 years ago. J Urol 1983; 129: 1120 - 1122.

3 Maynard FM, Diokno AC. Urinary infection and complications during clean intermittent catheterization following spinal cord injury. J Urol 1984; 182: $943-946$.

4 Wyndaele JJ, Maes D. Clean intermittent self-catheterization: a 12-year followup. J Urol 1990; 143: $906-908$.

5 Lapides J, Diokno AC, Silber SJ, Lowe BS. Clean intermittent self-catheterisation in the treatment of urinary tract disease. $J$ Urol 1972; 107: $458-461$

6 Dailey J, Michael R. Non sterile self-intermittent catheterisation for male quadriplegic patients. Am J Occup Ther 1977; 31: 86 - 89.

7 Guttman L, Frankel H. The value of intermittent self catheterisation in the early management of traumatic paraplegia and tetraplegia. Paraplegia 1966; 4: 63.

8 Lapides J, Diokno AC, Silber SJ, Lowe BS. Clean intermittent self-catheterization in the treatment of urinary tract disease. Trans Am Assoc Genitourin Surg 1975; 67: 15-17.

9 Wyndaele JJ, Oosterlinck W, De Sy W. Clean intermittent selfcatheterization in the chronic management of the neurogenic bladder. Eur Urol 1980; 6: 107-110.

10 Cass AS et al. Clean intermittent catheterization in the management of the neurogenic bladder in children. J Urol 1984; 132: 526.

11 Labat $\mathrm{JJ}$ et al. L'autosondage intermittent propre dans la reéducation des blessés medullaires et de la queue de cheval I. Ann Réadapt Méd Phys 1985; 28: 111.

$12 \mathrm{Webb}$ RJ, Lawson AL, Neal DE. Clean intermittent selfcatheterisation in 172 adults. Br J Urol 1990; 65: 20.

13 Bakke A, Vollset SE, Hoisaeter PA, Irgens LM. Physical complications in patients treated with clean intermittent catheterization. Scand J Urol Nephrol 1993; 27: 55.

14 Perrouin-Verbe B et al. Clean intermittent catheterisation from the acute period in spinal cord injury patients. Long term evaluation of urethral and genital tolerance. Paraplegia 1995; 33: $619-624$

15 Maynard FM, Glass J. Management of the neuropathic bladder by clean intermittent catheterisation : 5 year outcome. Paraplegia 1987: 25: 106.

16 Waller L, Telander M, Sullivan L. The importance of osmolality in hydrophilic urethral catheters: a crossover study. Spinal Cord 1997; 35: 229-233.

17 Hellstrom P, Tammela T, Lukkarinen O, Kontturi M. Efficacy and safety of clean intermittent catheterisation in adults. Eur Urol 1991; 20: $117-121$.

18 Waller L, Jonsson O, Norlen L, Sullivan L. Clean intermittent self catheterization in spinal cord injury patients: Long-term followup of a hydrophylic low friction technique. J Urol 1995; 153: 345.

19 Koleilat N, Sidi AA, Gonzalez R. Urethral false passage as a complication of intermittent catheterisation. J Urol 1989; 142: 1216.

20 Mandal AK, Vaidyanathan S. Management of urethral stricture in patients practising clean intermittent catheterisation. Int Urol Nephrol 1993; 25: 395. 